\title{
Role of histamine release in hypertonic saline induced bronchoconstriction
}

\author{
STEPHEN P O'HICKEY, NICK G BELCHER, P JOHN REES, TAK H LEE \\ From the Departments of Allergy and Allied Respiratory Disorders and of Respiratory Medicine, United \\ Medical and Dental Schools, Guy's Hospital, London
}

ABSTRACT In a study designed to determine the protective effect of the specific histamine $\mathrm{H}_{1+\infty}$ antagonist terfenadine on hypertonic saline induced bronchoconstriction, 10 asthmatic subjects. underwent hypertonic saline challenge (3.6\%) after premedication with placebo or terfenadine (120\% mg) 12 and two hours before the challenge. Hypertonic saline was administered in a dose dependento manner and the response determined as the dose of hypertonic saline that induced a $20 \%$ fall in $\mathrm{FEV}_{1} \rightarrow$ $\left(\mathrm{PD}_{20} \mathrm{FEV}_{1}\right) . \mathrm{FEV}_{1}$ was on average $11 \%$ greater with terfenadine than with placebo given before the challenge with hypertonic saline. $\mathrm{PD}_{20} \mathrm{FEV}_{1}$ was attenuated by a mean of 2.5 fold after terfenadineo

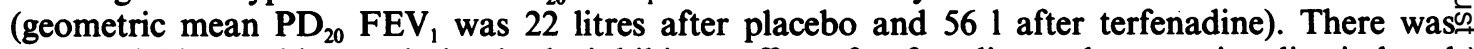
substantial intersubject variation in the inhibitory effect of terfenadine on hypertonic saline induced $\overrightarrow{{ }_{0}}$ bronchoconstriction: the ratio of the $\mathrm{PD}_{20}$ hypertonic saline after terfenadine to that after placeboo ranged from 0.9 to 10.0 . Terfenadine inhibited histamine induced bronchoconstriction in the eight subjects in whom it was tested, by 13 to 160 fold compared with placebo in four subjects and by $>2$ to $>9$ fold in the four who showed no response to the highest dose of histamine given $(16 \mathrm{mg} / \mathrm{ml})$. These results suggest that histamine release has a role in hypertonic saline induced bronchoconstriction in\% some individuals; other mediators or mechanisms may have a more prominent role in others.

\section{Introduction}

Inhalation of hypertonic saline elicits bronchoconstriction in many people with asthma. ${ }^{12}$ Airway responsiveness to aerosolised hypertonic saline has been shown to be correlated with responsiveness to inhaled methacholine, ${ }^{34}$ histamine, ${ }^{5}$ and exercise. ${ }^{6}$ In common with inhalation of ultrasonically nebulised distilled water ${ }^{7}$ and exercise induced asthma,${ }^{8}$ the inhalation of hypertonic saline may be followed by the development of a refractory period during which a second, identical challenge will cause significantly less bronchoconstriction. ${ }^{9}$ Hypertonic saline induced bronchoconstriction is accompanied by the release of high molecular weight neutrophil chemotactic activity, ${ }^{10}$ suggesting that mast cell associated mediators may be released by the hyperosmolar stimulus to the bronchial mucosa. It is not, however, associated with an increase in venous plasma histamine concentrations, ${ }^{10}$ though histamine is released in vivo, as judged by measurements made

Address for reprint requests: Professor T H Lee, Department of Allergy and Allied Respiratory Disorders, Hunts House, Guy's Hospital, London SE1 9RT.

Accepted 9 May 1989 on bronchoalveolar lavage fluid. ${ }^{11}$ It has been suggested that hypertonic saline inhalation may release histamine locally in the airways, but that the quantities produced are too small to be detected in the systemion circulation. ${ }^{10}$

We have assessed the role of histamine release in hypertonic saline induced bronchoconstriction by? determining the effect of terfenadine, a potent ando selective histamine $H_{1}$ receptor antagonist, on the airway responsiveness to hypertonic saline.

\section{Methods}

\section{SUBJECTS}

We studied 10 asthmatic subjects (seven male, three female) aged 19-47 (mean 25.5) years. Nine subjects ${ }^{\omega}$ were taking regular inhaled beclomethasone dipropionate (dose 200-1000 $\mu \mathrm{g}$ daily), and all used? inhaled beta ${ }_{2}$ sympathomimetic agonists as required. $\mathbb{D}^{\circ}$ Nine subjects were atopic as defined by positive skin ${ }_{-}^{+}$ test responses (a weal at least $3 \mathrm{~mm}$ larger than with the saline control solution) to a range of common $\overrightarrow{0}$ aeroallergens (grass, dog, cat, Dermatophagoides $\frac{?}{\mathbb{D}}$ pteronyssinus). No subject had taken oral corticosteroids for at least one month before challenge and no? 
subject was taking other antiasthmatic drugs (including histamine antagonists).

\section{STUDY DESIGN}

Ten subjects underwent two hypertonic saline challenges separated by one week. Each challenge was preceded by the administration of either $120 \mathrm{mg}$ terfenadine or matching placebo capsules in a double blind manner 12 and two hours before the hypertonic saline challenge. Eight of the 10 subjects also underwent two histamine challenges preceded by the administration of terfenadine or matching placebo, as described above. All other medication was withheld for 12 hours before each visit to the laboratory. All challenges for each subject were performed at the same time of day. The study was approved by the Guy's Hospital ethical committee and each subject gave informed consent.

\section{HYPERTONIC SALINE CHALLENGE}

Hypertonic saline challenges were performed with a Devilbiss 65 Ultrasonic nebuliser as previously described. ${ }^{9}$ The subject inhaled twofold increasing volumes of hypertonic (3.6\%) saline, starting at 5 litres, until there was a greater than $20 \%$ fall in FEV or until a maximum cumulative dose of 315 litres of hypertonic saline was reached. Measurements of FEV were made in duplicate on a dry bellows spirometer (Vitalograph, Buckingham) at 30,60, and 90 seconds after each dose of hypertonic saline and the highest reading was recorded. If the required decrease in $\mathrm{FEV}_{1}$ was not reached the next dose of saline was given. The dose of hypertonic saline producing a $20 \%$ fall in $\mathrm{FEV}_{1}\left(\mathrm{PD}_{20}\right)$ was determined by linear interpolation of the last two points of the log dose-response curve.

\section{HISTAMINE CHALLENGE}

Histamine acid phosphate in isotonic buffered saline was delivered from a Wright nebuliser driven at a flow rate of $8 \mathrm{l} / \mathrm{min}$ at $20 \mathrm{lb} / \mathrm{in}^{2}(138 \mathrm{kPa}$; output $0.14 \mathrm{ml} /$ $\mathrm{min})$. Histamine was inhaled during two minutes of tidal breathing. Doubling concentrations from $0.0625 \mathrm{mg} / \mathrm{ml}$ were used until a $20 \%$ fall in FEV, was achieved or a maximum concentration of $16.0 \mathrm{mg} / \mathrm{ml}$ was delivered. The FEV , was measured 0.5 , one, and three minutes after inhalation of histamine and the concentration of histamine required to produce a $20 \%$ fall in FEV $\left(\mathbf{P C}_{20}\right.$ histamine) was determined by linear interpolation from the last two points of the log doseresponse curve.

DATA ANALYSIS

Differences in $\mathrm{PD}_{20}$ hypertonic saline between placebo and terfenadine days were analysed by a paired $t$ test of log transformed data. Correlations were assessed by linear regression analysis of the log transformed data.
Results

EFFECT OF TERFENADINE ON AIR WAY RESPONSE TO HYPERTONIC SALINE

The mean (SEM) FEV 1 was significantly less after administration of placebo $(3.06(0.19) 1)$ than of terfenadine $(3.38(0.22) \mathrm{l} ; \mathrm{p}=0.009)$. The airway response to hypertonic saline was significantly attenuated by terfenadine (table 1). The geometric mean $\mathrm{PD}_{20}$ hypertonic saline was 22 (range 3-235) litres after placebo and 56 (range 10-315) after terfenadine $(p=0.007, n=10 ;$ table 1$)$. There was a 10 fold variation between subjects in the change in $\mathrm{PD}_{20}$ hypertonic saline after terfenadine premedication (table 1). The change in $\mathrm{PD}_{20}$ hypertonic saline after terfenadine was not correlated with resting FEV $_{1}$ before hypertonic saline challenge on the terfenadine or placebo days $(r=0.2, p=0.5)$, or with the subject's daily dose of inhaled beclomethasone dipropionate $(r=-0.17, p=0 \cdot 6)$.

\section{EFFECT OF TERFENADINE ON AIRWAY RESPONSE} TO HIST AMINE

Two of the 10 subjects declined histamine challenge. In the other eight subjects terfenadine caused significant protection against histamine bronchoconstriction ( $p=0.001$ ), the ratio of $\mathrm{PC}_{20}$ histamine following terfenadine to that following placebo ranging from $>2.0$ to 160 fold (table 2). Four of the five subjects in whom terfenadine caused minimal or no protection against hypertonic saline induced bronchoconstriction (subjects 2, 7,8, and 9) underwent histamine challenge; all were protected against histamine induced bronchoconstriction.

Table 1 FEV, after placebo and terfenadine, the dose of hypertonic saline that produced a $20 \%$ fall in $F E V_{1}\left(P D_{20}\right)$ after placebo and terfenadine, and the ratio of $P D_{20}$ terfenadine to $P D_{20}$ placebo

\begin{tabular}{|c|c|c|c|c|c|}
\hline \multirow[b]{2}{*}{$\begin{array}{l}\text { Subject } \\
\text { No }\end{array}$} & \multicolumn{2}{|l|}{ Placebo } & \multicolumn{2}{|c|}{ Terfenadine } & \multirow[b]{2}{*}{$\begin{array}{l}P D_{20} \\
\text { ratio }\end{array}$} \\
\hline & $\begin{array}{l}\text { FEV } \\
\text { (litres) }\end{array}$ & $\begin{array}{l}P D_{20} \\
\text { (litres) }\end{array}$ & $\begin{array}{l}F E V_{1} \\
\text { (litres) }\end{array}$ & $\begin{array}{l}P D_{20} \\
\text { (litres) }\end{array}$ & \\
\hline $\begin{array}{r}1 \\
2 \\
3 \\
4 \\
5 \\
6 \\
7 \\
8 \\
9 \\
10\end{array}$ & $\begin{array}{l}2.2 \\
3.4 \\
3 \cdot 1 \\
3.5 \\
3 \cdot 8 \\
2.4 \\
2.6 \\
2.4 \\
3.5 \\
3.7\end{array}$ & $\begin{array}{r}25 \\
7 \\
14 \\
14 \\
36 \\
3 \\
24 \\
37 \\
35 \\
235\end{array}$ & $\begin{array}{l}2 \cdot 2 \\
3 \cdot 7 \\
3 \cdot 9 \\
3 \cdot 7 \\
3 \cdot 7 \\
2 \cdot 8 \\
2 \cdot 6 \\
2.9 \\
4 \cdot 3 \\
4 \cdot 0\end{array}$ & $\begin{array}{r}200 \\
10 \\
100 \\
33 \\
92 \\
30 \\
23 \\
43 \\
58 \\
315\end{array}$ & $\begin{array}{r}8.0 \\
1.4 \\
7 \cdot 1 \\
2.3 \\
2.5 \\
10 \cdot 0 \\
0.9 \\
1.2 \\
1.6 \\
1.3\end{array}$ \\
\hline Mean* & 3.06 & 22 & $3 \cdot 38$ & 56 & $2 \cdot 5$ \\
\hline
\end{tabular}

*Arithmetic mean for $\mathrm{FEV}_{1}$ and geometric mean for $\mathrm{PD}_{20}$. 
Table $2 F E V$, after placebo and terfenadine, the concentration of histamine that produced a $20 \%$ fall in FEV, $\left(P C_{20}\right)$ after placebo and after terfenadine, and the ratio of $P C_{20}$ histamine after terfenadine to $P C_{20}$ histamine after placebo

\begin{tabular}{|c|c|c|c|c|c|}
\hline \multirow[b]{2}{*}{$\begin{array}{l}\text { Subject } \\
\text { No }\end{array}$} & \multicolumn{2}{|l|}{ Placebo } & \multicolumn{2}{|c|}{ Terfenadine } & \multirow[b]{2}{*}{$\begin{array}{l}P C_{20} \\
\text { ratio }\end{array}$} \\
\hline & $\begin{array}{l}\text { FEV } \\
\text { (litres) }\end{array}$ & $\begin{array}{l}P C_{20} \\
(m g / m l)\end{array}$ & $\begin{array}{l}F E V_{1} \\
\text { (litres) }\end{array}$ & $\begin{array}{l}P C_{20} \\
(m g / m l)\end{array}$ & \\
\hline $\begin{array}{l}2 \\
3 \\
4 \\
5 \\
6 \\
7 \\
8 \\
9\end{array}$ & $\begin{array}{l}3.6 \\
2.7 \\
2.7 \\
3 \cdot 5 \\
2.4 \\
2 \cdot 1 \\
3 \cdot 4 \\
3.5\end{array}$ & $\begin{array}{l}8.00 \\
2.30 \\
1.80 \\
2.30 \\
0.13 \\
0.58 \\
1.00 \\
0.05\end{array}$ & $\begin{array}{l}3 \cdot 9 \\
3 \cdot 8 \\
2 \cdot 2 \\
3 \cdot 8 \\
2.5 \\
2 \cdot 4 \\
2 \cdot 7 \\
3 \cdot 8\end{array}$ & $\begin{array}{r}>16.0 \\
>16.0 \\
>16.0 \\
>16.0 \\
12.0 \\
8.0 \\
16.0 \\
8.0\end{array}$ & $\begin{array}{l}>2 \\
>6.9 \\
>8.9 \\
>6.9 \\
92.3 \\
13.8 \\
16.0 \\
160.0\end{array}$ \\
\hline Mean & 3.0 & & $3 \cdot 1$ & & \\
\hline
\end{tabular}

\section{Discussion}

Intrabronchial challenge of the airways with hypertonic saline in vivo results in the local release of histamine, suggesting that this mediator may contribute to bronchoconstriction." This view is supported by the results of the present cumulative dose-response study, which showed a significant reduction in airway responsiveness to hypertonic saline after premedication with the potent and selective histamine $\mathrm{H}_{1}$ receptor antagonist terfenadine. The dose of terfenadine given has been shown to attenuate the airway response to inhaled histamine. ${ }^{12}$ Terfenadine induced a significant degree of bronchodilatation but this was not related to the change in airway responsiveness and there was no correlation between the degree of bronchodilatation and the magnitude of the decreases in responsiveness to hypertonic saline. As a drug that alters baseline airway calibre may influence the position of the dose-response curve of a bronchoconstrictor agonist, we have followed the principle of Chung et al and "normalised" the bronchoconstrictor dose-response curve to the postdrug baseline, thereby removing the influence of baseline airway calibre on the bronchoconstrictor response. ${ }^{13}$ Using this procedure, Rafferty and Holgate $^{12}$ and Patel $^{14}$ have shown that although terfenadine causes bronchodilatation it does not alter airway responsiveness to inhaled methacholine, as determined by $\mathrm{PD}_{20} \mathrm{FEV}_{1}$. This indicates that bronchodilatation produced by terfenadine will not necessarily change $\mathrm{PD}_{20}$.

Although the group as a whole had a significant reduction in airway responsiveness to hypertonic saline after terfenadine pretreatment, the protection afforded by terfenadine was variable. As terfenadine inhibited histamine induced bronchoconstriction in all the subjects studied, the intersubject variability cannot:be ascribed to a failure of terfenadine to inhibit thes? bronchoconstrictor action of histamine. The reasono for the variable response is not known, but may reflecto heterogeneity in the mechanisms responsible for hypertonic saline induced bronchoconstriction. II suggests that, although histamine release contributesw to the pathogenesis of hypertonic saline induced" asthma in some patients, other mediators or? mechanisms may be important in other individuals. $\overrightarrow{\vec{\omega}}$

There is continuing debate about the mechanism of exercise induced asthma. ${ }^{15}$ McFadden et al have्ट्र suggested that respiratory heat loss ${ }^{16}$ is of major importance and that the rate of airway rewarming ${ }_{\infty}^{+}$ after exercise determines the degree of bronchoin constriction. ${ }^{17}$ Anderson and co-workers haves suggested that change in bronchial mucosap osmolarity secondary to water loss during the hyper-pnoea of exercise is the major factor in exerciser induced asthma. ${ }^{18}$ In support of this, Ingenito and coo workers, ${ }^{19}$ using gases with similar water carryinge? capacities but significantly different volume-heat capacities, recently showed that total respiratory heapo loss is not the primary stimulus in exercise induced asthma, and that water loss may be important in inducing bronchoconstriction in exercise induceds asthma.

If hyperosmolarity is the cause of exercise inducec\% asthma, the pharmacological modulation of hypero tonic saline induced bronchoconstriction and exercise $\overrightarrow{\vec{b}}$ induced asthma should be identical. In support of this $\bar{乛}$ our results with hypertonic saline induced broncho? constriction are similar to those of Patel, ${ }^{20}$ who found small but significant protective effect of terfenadine on postexertional bronchoconstriction in 10 subjects $\frac{\text { 엉 }}{2}$ though in three no protection was seen after 60,120 , of $180 \mathrm{mg}$ terfenadine administered three hours before exercise. Magnussen in a study of a single dose of azelastine $(4.4 \mathrm{mg})$ showed significant attenuation of exercise induced asthma in 10 subjects, though three of these were not protected. ${ }^{21}$

In this study we have shown that the potent and selective histamine $H_{1}$ receptor antagonist terfenadine confers partial protection against hypertonic salinf induced bronchoconstriction in some subjects. These results suggest that histamine release has a role in the bronchoconstriction induced by this challenge, but the pathogenetic mechanisms of hyperosmolar challenge may be heterogeneous.

This study was supported in part by the Asthma Research Council.

\section{References}

1 Schoeffel RE, Anderson SD, Altounyan REC. Bronchia? hyperreactivity in response to inhalation of ultrae 
sonically nebulised solutions of distilled water and saline. $\mathrm{Br}$ Med J 1981;283:1285-7.

2 Anderson SD, Schoeffel RE, Finney M. Evaluation of ultrasonically nebulised solutions for provocation testing in patients with asthma. Thorax 1983;38:284-91.

3 O'Hickey SP, Arm JP, Rees PJ, Lee TH. Airways responsiveness to methacholine after inhalation of nebulised hypertonic saline challenge in bronchial asthma. J Allergy Clin Immunol 1989;83:472-6.

4 Smith CM, Anderson SD, Black JL. Methacholine responsiveness increases after ultrasonically nebulized water but not after ultrasonically nebulized hypertonic saline in patients with asthma. $J$ Allergy Clin Immunol 1987;79:85-92.

5 Belcher N, Lee TH, Rees PJ. Airway responses to hypertonic saline, exercise and histamine challenges in bronchial asthma. Eur J Respir 1989;2:44-8.

6 Turcotte H, Boulet LP. Bronchial reactivity to hyperosmolar saline: a comparison with response to methacholine and exercise [abstract]. $J$ Allergy Clin Immunol 1987;79:148.

7 Mattoli S, Foresi A, Corbo GM, et al. Refractory period to ultrasonic mist of distilled water: relationship to methacholine responsiveness, atopic status, and clinical characteristics. Ann Allergy 1987;58:134-40.

8 Edmunds T, Tooley M, Godfrey S. The refractory period after exercise induced asthma: its duration and relation to severity of exercise. Am Rev Respir Dis 1978;117:247-54.

9 Belcher NG, Rees PJ, Clark TJH, Lee TH. A comparison of the refractory periods induced by hypertonic airway challenge and exercise in bronchial asthma. Am Rev Respir Dis 1987;135:822-5.

10 Belcher NG, Murdoch RD, Dalton N, et al. A comparison of mediator and catecholamine release between exercise- and hypertonic saline-induced asthma. Am Rev Respir Dis 1988;137:1026-32.

11 Gravelyn TR, Pan PM, Eschenbacher WL. Mediator release in an isolated airway segment in subjects with asthma. Am Rev Respir Dis 1988;137:636-40.

12 Rafferty P, Holgate ST. Terfenadine is a potent and selective histamine $\mathrm{H}_{1}$ receptor antagonist in asthmatic airways. Am Rev Respir Dis 1987;135:181-4.

13 Chung KF, Morgan B, Keyes SJ, Snashall PD. Histamine dose-response relationships in normal and asthmatic subjects. Am Rev Respir Dis 1982;126:849-54.

14 Patel KR. Effect of terfenadine on methacholine-induced bronchoconstriction in asthma. J Allergy Clin Immunol 1987;79:355-8.

15 Gilbert I, Fouke JM, McFadden ER. Heat and water flux in the intrathoracic airways and exercise-induced asthma. J Appl Physiol 1987;63:1681-91.

16 Deal EC, McFadden ER, Ingram RH, Jaeger JJ. Hyperpnoea and heat flux: initial reaction sequence in exercise-induced asthma. J Appl Physiol 1979;46: 467-83.

17 McFadden ER, Lenner KA, Strohl KP. Postexertional airway rewarming and thermally induced asthma. $J$ Clin Invest 1986;78:18-25.

18 Anderson SD. Is there a unifying hypothesis for exerciseinduced asthma? J Allergy Clin Immunol 1984;73: 660-5.

19 Ingenito E, Solway J, Lafleur J, Lombardo A, Drazen JM, Pirchurko B. Dissociation of temperaturegradient and evaporative heat loss during cold gas hyperventilation in cold-induced asthma. Am Rev Respir Dis 1988;138:540-6.

20 Patel KR. Terfenadine in exercise-induced asthma. $\mathrm{Br}$ Med J 1984;288:1496-7.

21 Magnussen M, Reuss G, Jorres R, Aurich R. The effect of azelastine on exercise-induced asthma. Chest 1988;93:937-40. 